\title{
ARTIKEL
}

\section{PENELITIAN PRATAMA}

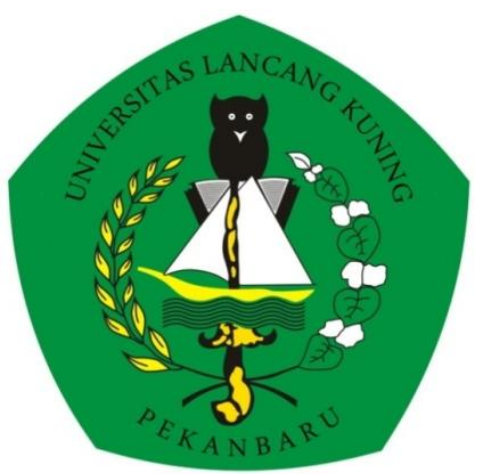

\section{ANALISIS KINERJA BANK SWASTA STUDI KASUS PADA BANK DANAMON, CITIBANK, BANK PERMATA}

\section{Oleh:}

Rita Wiyati.SE.,MM (Ketua)

Drs. M. Thamrin, MM (Anggota)

Liviawati, SE, M.Si. Ak (Anggota)
NIDN: 1025037201

NIDN: 1019045801

NIDN: 1012027201

Penelitian ini Dibiayai oleh APBF Fakultas Ekonomi Universitas Lancang KuningPekanbaru, sesuai dengan Surat Perjanjian Pelaksanaan Penelitian Nomor: 053/Unilak.02/UPPM/B.07/2015 



\title{
ABSTRACT \\ Performance Analysis Case Study On Private Bank Danamon Bank, City Bank, and Bank Permata
}

\author{
By: \\ Rita Wiyati, Liviawati, M.Thamrin
}

Banking company performance reflects the true condition of the company because it contains information about each business unit that can be achieved by the company within a certain period. Reports of the company's financial performance is a must to be reported periodically if the company has gone public or registered Stock Market Securities Indonesia.

Research on the financial performance of the banking industry which is based on financial ratios pernh done before by Sumarta (2000), conducted a research on the evaluation of the performance of banking companies listed dibursa Securities Indonesia and Thailand before the financial crisis of 1997 consisted of 12 banks in Indonesia and 16 banks in Thailand, using CAMEL, the results of these studies show that commercial banks in Indonesia can be said to be better than Commercial banks in Thailand.

A study conducted by Infobank (2014) related to the preparation of the national banking ratings can be said diindustri banking competition lately lasted very tight, the shifting position dijajaran 10 largest banks is inevitable, both in terms of assets, deposits, and loans. The top spot still held by the bank, the seco nd position in the hands of Bank Rakyat Indonesia. Meanwhile, some other banks that dropped him are Bank Danamon and Bank Permata. Danamon shifted from position five keperingkat six. Gem also down to ten of the top eight. In fact, Citybank bounced from the top 10 .

This study was conducted to analyze the performance of banks jewel, danamon banks and city banks. In analyzing the data using quantitative descriptive method with approach Camel method is to calculate the bank's performance with regard Capital, Assets, Management, Earnings and Liquidity by calculating the ratio that takes the data from the financial statements of the three banks that want to analyze their performance, and connect with a theory that can support in the discussion.

Based on the results of research known gem bank performance, bank Danamon and city banks in 2013 decreased when compared to 2012. The decline in bank performance Permata, Bank Danamon and the City is not to interfere with his health. Despite a decline in performance in 2013, but three banks above still considered healthy banks. A decrease in the performance of the three banks namely Bank Permata, Danamon and city banks was largely due to the inefficient operation of the bank where it can be seen from the increase in ROA for each bank. The third Bank has BOPO value rose in 2013 compared to 2012. 


\title{
ABSTRACT \\ Analisis Kinerja Bank Swasta Studi Kasus Pada Bank Danamon, City Bank, dan Bank Permata
}

\author{
Oleh: \\ Rita Wiyati, Liviawati, M.Thamrin
}

\begin{abstract}
Kinerja perusahaan perbankan mencerminkan kondisi perusahaan yang sesungguhnya karena memuat informasi setiap unit usaha yang dapat dicapai perusahaan dalam periode tertentu. Laporan dari kinerja keuangan perusahaan menjadi suatu keharusan untuk dilaporkan secara periodik apabila perusahaan tersebut telah go public atau terdaftar diBursa Efek Indonesia.

Penelitian mengenai kinerja keuangan pada industri perbankan yang didasarkan pada rasio keuangan pernh dilakukan sebelumnya oleh Sumarta (2000), melakukan penelitian mengenai evaluasi kinerja perusahaan perbankan yang terdaftar dibursa Efek Indonesia dan Thailand sebelum krisis keuangan tahun1997 terdiri dari 12 bank diIndonesia dan 16 bank diThailand, menggunakan CAMEL, hasil penelitian tersebut menunjukkan bahwa bank umum diIndonesia dapat dikatakan lebih baik dibandingkan bank Umum diThailand.
\end{abstract}

Kajian yang dilakukan oleh Infobank (2014) terkait dengan penyusunan peringkat perbankan nasional dapat dikatakan persaingan diindustri perbankan akhir akhir ini berlangsung sangatlah ketat, Pergerseran posisi dijajaran 10 bank terbesar tak terhindarkan, baik dari sisi asset, simpanan, dan kredit. Posisi teratas tetap dipegang oleh Bank Mandiri,posisi kedua ditangan Bank Rakyat Indonesia. Sedangkan, beberapa bank lain yang posisinya turun adalah Bank Danamon dan Bank Permata. Danamon bergeser dari posisi lima keperingkat enam. Permata juga turun ke sepuluh dari posisi delapan. Bahkan, Citybank terpental dari 10 besar.

Penelitian ini dilakukan dengan tujuan untuk menganalisis kinerja bank permata,bank danamon dan city bank. Dalam menganalisis data menggunakan metode deskriptif kuantitaif dengan pendekatan metode Camel yaitu menghitung kinerja bank dengan memperhatikan Capital, Asset, Manajemen, Earning dan Likuiditas dengan cara menghitung rasionya yang mengambil data dari laporan keuangan ketiga bank yang mau dianalisis kinerjanya, dan menghubungkan dengan teori yang dapat mendukung dalam pembahasan.

Berdasarkan hasil penelitian diketahui Kinerja bank Permata,bank Danamon dan city bank tahun 2013 menurun jika dibandingkan 2012. Penurunan kinerja bank Permata,Danamon dan City bank ini tidak sampai mengganggu kesehatannya. Walaupun terjadi penurunan kinerja pada 2013 tetapi ketiga bank diatas masih dikategorikan bank yang sehat. Penurunan kinerja ketiga bank yaitu bank Permata,Danamon dan city bank itu sebagian besar disebabkan karena operasi bank yang tidak efisien dimana hal ini bisa kita lihat dari peningkatan BOPO untuk masing-masing bank. Ketiga Bank tersebut mempunyai nilai BOPO yang naik pada tahun 2013 dibandingkan tahun 2012. 


\section{PENDAHULUAN}

Bank merupakan lembaga keuangan yang menghimpun dana dari masyarakat dalam bentuk simpanan dan menyalurkannya dalam bentuk kredit kepada masyarakat yang membutuhkan dana. Bank bukanlah suatu hal yang asing bagi masyarakat di negara maju. Bank dianggap sebagai suatu lembaga keuangan yang aman dalam melakukan berbagai macam aktivitas keuangan. Bank sangat dibutuhkan oleh masyarakat baik masyarakat yang memiliki uang maupun masyarakat yang memerlukan uang untuk memenuhi kebutuhannya.

Bank Indonesia menilai kesehatan bank bank yang ada diIndonesia dengan cara mengawasi kinerja keuangan setiap tahunnya. Kegiatan ini mempunyai tujuan untuk dapat membantu manajemen bank, apakah telah dikelola dengan prinsip kehati hatian dan sistem perbankan yang sehat, serta sesuai dengan peraturan Bank Indonesia. Kesehatan suatu bank merupakan kepentingan semua pihak terkait, baik pemilik dan pengelola bank, masyarakat pengguna jasa bank maupun Bank Indonesia selaku pembina dan pengawas bank. Penilaian kesehatan bank dilakukan dengan data keuangan yang berpengaruh terhadap kondisi dan perkembangan suatu bank yang meliputi faktor permodalan, lualitas aktiva produktif, manajemen, rentabilitas, likuiditas. Masyarakat sebagai pemilik dana yang diinvestasikan kepada bank dalam bentuk rekening giro, tabungan, deposito, dan berbagai jenis simpanan lainnya, menginginkan hasil yang cukup memadai dan dana miliknya aman.

Kinerja perusahaan perbankan mencerminkan kondisi perusahaan yang sesungguhnya karena memuat informasi setiap unit usaha yang dapat dicapai perusahaan dalam periode tertentu. Laporan dari kinerja keuangan perusahaan menjadi suatu keharusan untuk dilaporkan secara periodik apabola perusahaan tersebut telah go public atau terdaftar diBursa Efek Indonesia (BEI).

Penelitian mengenai kinerja keuangan pada industri perbankan yang didasarkan pada rasio keuangan pernh dilakukan sebelumnya oleh Sumarta (2000), melakukan penelitian mengenai evaluasi kinerja perusahaan perbankan yang terdaftar dibursa Efek Indonesia dan Thailand sebelum krisis keuangan tahun 1997 terdiri dari 12 bank diIndonesia dan 16 bank diThailand, menggunakan CAMEL, hasil penelitian tersebut menunjukkan bahwa bank umum diIndonesia dapat dikatakan lebih baik dibandingkan bank Umum diThailand.

Namun demikian kajian yang dilakukan oleh Infobank (2014) terkait dengan penyusunan peringkat perbankan nasional dapat dikatakan persaingan diindustri perbankan akhir akhir ini berlangsung sangatlah ketat, Pergerseran posisi dijajaran 10 bank terbesar tak terhindarkan, baik dari sisi asset, simpanan, dan kredit. Posisi teratas tetap dipegang oleh Bank Mandiri, Bank milik negara gabungan dari empat bank dengan total asset Rp 375 triliun. Posisi kedua ditangan Bank Rakyat Indonesia dengan total asset Rp. 318 triliun. Sedangkan, beberapa bank lain yang posisinya turun adalah Bank Danamon dan Bank Permata. Danamon bergeser dari posisi lima keperingkat enam. Permata juga turun ke sepuluh dari posisi delapan. Bahkan, Citybank terpental dari 10 besar.

Berdasarkan Uraian diatas , peneliti tertarik meneliti dengan judul : “ Analisis Kinerja Bank Swasta Studi Kasus Pada Bank Danamon, City Bank, dan 
Bank Permata " dengan rumusan maslaha sebagai berikut: Bagaimanakah kinerja Bank Danamon,City bank dan Bank Permata sehingga menyebabkan peringkat ketiga bank ini turun?

\section{Pengertian Bank}

\section{TINJAUAN PUSTAKA}

Pengertian bank secara umum adalah lembaga keuangan yang kegiatan usahanya adalah menghimpun dana dari masyarakat dan menyalurkan kembali dana tersebut ke masyarakat serta memberikan jasa-jasa bank lainnya.

Menurut pendapat Danang Sunyoto $(2013 ; 32)$ Bank umum adalah bank yang bertugas melayani seluruh jasa-jasa perbankan untuk setiap lapisan masyarakat, baik secara orang perorangan maupun lembaga-lembaga lainnya. Menurut pendapat Ismail $(2010 ; 12)$, Bank merupakan lembaga keuangan yang fungsi utamanya adalah menghimpun dana dari masyarakat, menyalurkan dana kepada masyarakat, dan juga memberikan pelayanan dalam bentuk jasa-jasa perbankan.

Bank adalah salah satu badan usaha finansial yang menghimpun dana dari masyarakat dalam bentuk simpanan dan menyalurkannya kepada masyarakat dalam bentuk kredit dan/atau bentuk-bentuk lainnya dalam rangka meningkatkan taraf hidup masyarakat banyak. Dalam buku Herman Darmawi Bank menurut Undang-Undang No.10 Tahun 1998 adalah suatu badan usaha yang menghimpun dana dari masyarakat dalam bentuk simpanan dan menyalurkannya ke masyarakat dalam bentuk kredit dan atau bentuk-bentuk lainnya dalam rangka meningkatkan taraf hidup rakyat banyak.

Dilihat dari beberapa pengertian bank diatas, maka kegiatan bank merupakan hal yang penting dalam menyediakan jasa keuangan.

\section{Kegiatan Bank Secara Umum}

Berdasarkan Undang-Undang No.10 Tahun 1998 tentang Perbankan, secara tegas dinyatakan kegiatan-kegiatan yang boleh dilakukan oleh perbankan adalah sebagai berikut :

1. Menghimpun dana dari masyarakat dalam bentuk simpanan berupa giro, tabungan, deposito berjangka, sertifikat deposito dan/atau bentuk lainnya yang dipersamakan dengan itu.

2. Memberikan kredit.

3. Menerbitkan surat pengakuan utang/surat aksep.

4. Membeli, menjual, atau menjamin atas risiko sendiri maupun untuk kepentingan dan atas perintah nasabahnya.

Adapun Kegiatan Bank yang merupakan lembaga keuangan sebagai berikut:

1. Menghimpun dana (funding) dari masyarakat dalam bentuk simpanan, dalam hal ini bank sebagai tempat menyimpan uang atau berinvestasi bagi masyarakat.

2. Menyalurkan dana (lending) ke masyarakat, dalam hal ini bank memberikan pinjaman (kredit) kepada masyarakat. Dengan kata lain, bank menyediakan dana bagi masyarakat yang membutuhkannya.

3. Memberikan jasa-jasa bank lainnya (services) seperti pengiriman uang (transfer), penagihan surat-surat berharga yang berasal dari dalam kota 
(clearing), penagihan surat-surat berharga yang berasal dari luar kota dan luar negeri (inkaso), letter of credit (L/C), Safe deposit box, bank garansi, bank notes, travellers cheque, dan jasa lainnya.

\section{Penilaian Tingkat Kesehatan Bank}

Pasal 1 angka (4) PBI No. 6/10/PBI/2004 tentang Sistem Penilaian Tingkat Kesehatan Bank Umum, menyatakan bahwa Tingkat Kesehatan Bank adalah hasil penilaian kualitatif atas berbagai aspek yang berpengaruh terhadap kondisi atau kinerja suatu Bank melalui Penilaian Kuantitatif dan atau Penilaian Kualitatif terhadap faktor-faktor permodalan, kualitas aset, manajemen, rentabilitas, likuiditas, dan sensitivitas terhadap risiko pasar. (Zulfi Diane Zaini;2012;82)

Penilaian untuk menentukan kondisi suatu bank, biasanya menggunakan berbagai alat ukur. Salah satu alat ukur yang utama digunakan untuk menentukan kondisi suatu bank dikenal dengan nama analisis CAMEL. Aspek yang dinilai dalam analisis CAMEL yaitu :

1. Capital (Permodalan). Penilaian didasarkan kepada permodalan yang dimiliki oleh salah satu bank.

2. Assets (Kualitas aset). Penilaian didasarkan pada kualitas aktiva yang dimiliki oleh bank.

3. Management (Manajemen). Penilaian didasarkan pada manajemen permodalan, manajemen rentabilitas, manajemen likuiditas, dan manajemen umum.

4. Earning (Rentabilitas). Penilaian didasarkan pada rentabilitas suatu bank yang dilihat kemampuan suatu bank dalam menciptakan laba.

5. Liquidity (Likuiditas). Yaitu untuk menilai likuiditas bank.

\section{METODE PENELITIAN}

Didalam penelitian ini yang menjadi objek penelitian adalah kinerja Bank danamon, Citybank, dan Bank Permata

Adapun jenis data yang digunakan dalam penelitian ini adalah : Data Kuantitatif yaitu data yang berupa angka atau dapat dihitung dan dituangkan dalam bentuk tabel.Sedangkan sumber data dalam penelitian ini adalah data Sekunder yaitu data yang diperoleh dari laporan keuangan bank yang telah dipublikasikan

Dalam menganalisa data, peneliti menggunakan metode deskriptif kuantitaif dengan metode Camel yaitu menghitung kinerja bank dengan memperhatikan Capital, Asset, Manajemen, Earning dan Likuiditas dengan cara menghitung rasionya yang mengambil data dari laporan keuangan ketiga bank yang mau dianalisis kinerjanya, dan menghubungkan dengan teori yang dapat mendukung dalam pembahasan.

Disamping itu, peneliti menggunakan analisa rasio untuk membahas bagianbagian yang terdapat dalam laporan keuangan sehingga peneliti dapat mengetahui faktor-faktor yang mempengaruhi peringkat bank 


\section{Hasil Penelitian}

\section{HASIL PENELITIAN DAN PEMBAHASAN}

Kinerja bank adalah hasil kerja bank., Kinerja bank dapat dihitung dengan menggunakan indicator CAMEL dimana $\mathrm{C}$ adalah capital, A adalah kualitas aktiva, $\mathrm{M}$ adalah manajemen, $\mathrm{E}$ adalah Earning ( rentabilitas ) dan L adalah likuiditas.

\section{Capital}

Penilaian didasarkan kepada permodalan yang dimiliki oleh bank. Salah satu alat ukur untuk capital ( modal ) adalah CAR ( Capital adequacy ratio ) yaitu dengan membandingkan modal terhadap aktiva tertimbang menurut resiko (ATMR), atau CAR ini bisa juga dicari dengan rumus perbandingan antara Equity capital terhadap total loans ditambah securities.

Berdasarkan data yang termuat pada laporan posisi keuangan bank danamon, bank permata dan city bank maka besarnya CAR untuk masing-masing bank diatas adalah

Tabel 5.1

Capital adequacy ratio ( CAR )

\begin{tabular}{|c|c|c|c|c|}
\hline No & Tahun & Permata Bank & Bank Danamon & City Bank \\
\hline 1. & 2012 & $13,456 \%$ & $23,67 \%$ & $19,496 \%$ \\
\hline 2. & 2013 & $12,065 \%$ & $27,159 \%$ & $15,801 \%$ \\
\hline
\end{tabular}

Sumber : Data olahan hasil penelitian tahun 2015

Berdasarkan tabel CAR dari ketiga bank diatas terlihat bahwa ketiga bank mengalami penurunan CAR. CAR tahun 2012 lebih tinggi daripada CAR tahun 2013. Walaupun CAR tahun 2013 lebih rendah dari pada tahun 2013 namun CAR ketiga bank tersebut diatas masih diatas jumlah CAR yang ditentukan oleh bank Indonesia yaitu sebesar $9 \%$.

CAR ini adalah rasio yang menggambarkan kemampuan modal yang dimiliki oleh bank dalam menutupi resiko yang terjadi terutama resiko dari kredit yang diberikan kepada nasabah. Dengan memperhatikan tabel diatas berarti terjadi penurunan kemampuan modal bank permata,danamon dan city bank tahun 2013 dibandingkan 2012.

\section{Kualitas aktiva produktif}

Aktiva produktif yang dimaksud disini adalah aktiva berupa kredit yang diberikan oleh bank kepada nasabahnya. Kualitas aktiva produktif dapat diproksikan dengan return on asset. Rumus untuk mencari return on asset adalah perbandingan antara laba sebelum pajak dengan total asset.

Tabel 5.2

Return On Asset ( ROA )

\begin{tabular}{|l|c|c|c|c|}
\hline No & Tahun & Permata Bank & Bank Danamon & City Bank \\
\hline 1. & 2012 & $1,430 \%$ & $6 \%$ & $4,055 \%$ \\
\hline 2. & 2013 & $1,384 \%$ & $3,002 \%$ & $4,181 \%$ \\
\hline
\end{tabular}

Sumber : Data olahan hasil penelitian tahun 2015 
Jika dilihat dari perhitungan ROA pada tabel 4.2 diatas terlihat bahwa ROA tahun 2013 menurun dibandingkan ROA tahun 2012 dimana ini mengindasikan bahwa kualitas aseet bank dalam mengahsilkan laba menurun.

\section{Manajemen}

Pengukuran keberhasilan manajemen bank dalam mengendalikan aktifitas bisnisnya bisa diukur dengan rasio Net interest margin ( NIM ). NIM menggambarkan kemampuan manajemen dalam menghasilkan laba terutama dari bunga pinjaman yang diberika . Rumus untuk menghitung NIM adalah perbandingan antara pendapatan bunga bersih terhadap aktiva produktif. Aktiva produktif yang dimaksud disini adalah pinjaman yang diberikan pada nasabah bank. Dibawah ini adalah tabel NIM untuk bank danamon,city bank dan bank permata tahun 2012 dan 2013 :

Tabel 5.3

Net Interest Margin (NIM)

\begin{tabular}{|l|c|c|c|c|}
\hline No & Tahun & Permata Bank & Bank Danamon & City Bank \\
\hline 1. & 2012 & $5,584 \%$ & $14,73 \%$ & $9,767 \%$ \\
\hline 2. & 2013 & $5,011 \%$ & $3,002 \%$ & $7,494 \%$ \\
\hline
\end{tabular}

Sumber : Data olahan hasil penelitian tahun 2015

Kalau dilihat dari perhitungan Net Interest Margin diatas terlihat bahwa ketiga bank mengalami penurunan NIM. Yang berarti bahwa terjadi penurunan dalam kemampuan manajemen dalam menghasilkan laba.

\section{Earning (Rentabilitas)}

Rentabilitas adalah Penilaian yang didasarkan pada kemampuan suatu bank dalam menghasilkan laba. Penilaian dalam unsur ini didasarkan perbandingan rasio beban operasional dengan pendapatan operasional (BOPO).

Tabel 5.4

Earning (Rentabilitas) $=$ BOPO

\begin{tabular}{|l|c|c|c|c|}
\hline No & Tahun & Permata Bank & Bank Danamon & City Bank \\
\hline 1. & 2012 & $83,530 \%$ & $37 \%$ & $73,812 \%$ \\
\hline 2. & 2013 & $85,104 \%$ & $76,360 \%$ & $85,832 \%$ \\
\hline
\end{tabular}

Sumber : Data olahan hasil penelitian tahun 2015

Jika dilihat dari tabel BOPO diatas maka terjadi peningkatan rasio BOPO yang mengindikasikan bahwa opersional bank tersebut diatas tidak efektif.

\section{Liquidity (Likuiditas)}

Penilaian likuiditas bank didasarkan kepada rasio antara kredit terhadap dana yang diterima oleh Bank.Rasio likuidtas ini merupakan alat ukur untuk mengukur kemampuan bank dalam memenuhi kewajiban jangka pendeknya pada saat ditagih.Dengan kata lain, dapat membayar kembali pencairan dana deposannya pada saat ditagih serta dapat mencukupi permintaan kredit yang telah diajukan. 
Tabel 5.5

Liquidity (Likuiditas)

\begin{tabular}{|l|c|c|c|c|}
\hline No & Tahun & Permata Bank & Bank Danamon & City Bank \\
\hline 1. & 2012 & $89,507 \%$ & $98,036 \%$ & $73,850 \%$ \\
\hline 2. & 2013 & $88,684 \%$ & $93,335 \%$ & $88,336 \%$ \\
\hline
\end{tabular}

Sumber : Data olahan hasil penelitian tahun 2015

\section{Pembahasan}

Standar untuk penilain kesehatan bank menurut bank Indonesia setelah dirangkum dari tinjauan pustaka adalah sebagai berikut :

Tabel 5.6

Tabel kesehatan bank

\begin{tabular}{|c|c|c|c|c|c|}
\hline peringkat & CAR & NIM & LDR & ROA & BOPO \\
\hline $\begin{array}{c}\text { Sangat } \\
\text { sehat }\end{array}$ & $12 \%<\mathrm{CAR}$ & $2 \%<\mathrm{NIM}$ & $75 \%<\mathrm{LDR}$ & $2 \%<\mathrm{ROA}$ & $93,52 \%<\mathrm{BOPO}$ \\
\hline Sehat & $9 \%<\mathrm{CAR}<12 \%$ & $2 \%<\mathrm{NIM}<3 \%$ & $75 \%<\mathrm{LDR}<85 \%$ & $1,25 \%<\mathrm{ROA}<2 \%$ & $94 \%<\mathrm{BOPO}<95 \%$ \\
\hline
\end{tabular}

Sumber : Bank Indonesia

\section{Bank Permata}

Tabel 5.7

Kinerja bank permata

\begin{tabular}{|c|c|c|c|c|c|}
\hline Tahun & CAR & ROA & NIM & BOPO & LDR \\
\hline 2012 & $13,456 \%$ & $1,430 \%$ & $5,584 \%$ & $83,530 \%$ & $89,507 \%$ \\
\hline 2013 & $12,065 \%$ & $1,384 \%$ & $5,011 \%$ & $85,104 \%$ & $88,684 \%$ \\
\hline
\end{tabular}

Sumber: data olahan hasil penlitian tahun 2015

Jika dilihat dari tabel kinerja bank permata diatas terlihat bahwa kinerja bank permata tahun 2013 turun ketimbang kinerja tahun 2012. Kinerja bank permata 2013 masih dikatakan baik atau dengan kata lain masih dikategorikan sehat.

Penurunan kinerja bank permata jika dilihat dari tabel kinerja diatas disebabkan karena kemampuan manajemen menghasilkan pendapatan dari pinjaman menurun hal ini terlihat dari penuruan NIM,dimana penurunan NIM ini bisa salah satu disebabkan karena kualitas aktiva produktifnya menurun, penurunan kualitas aktivanya ditunjukkan dengan nilai ROA yang menurun pula. Kemudian jumlah dana pihak ketiga yang dikucurkan dalam bentuk pinjaman juga mengalami penurunan yang dapat dilihat dari penurunan LDR kemudian terjadi peningkatan BOPO yang mengindikasikan bahwa biaya operasinal bank tahun 2013 meningkat sedangkan pendapatan operasionalnya menurun.Peningkatan BOPO ini bisa saja disebabkan karena peningkatan biaya dari dana yang diterima dari pihak ketiga. Walaupun demikian bank masih memiliki permodalan diatas yang disyaratkan oleh bank Indonesia yaitu diatas $9 \%$ 
Bank Danamon

Tabel 5.8

Kinerja bank Danamon

\begin{tabular}{|c|c|c|c|c|c|}
\hline Tahun & CAR & ROA & NIM & BOPO & LDR \\
\hline 2012 & $23,67 \%$ & $6 \%$ & $14,73 \%$ & $37 \%$ & $98,036 \%$ \\
\hline 2013 & $27,159 \%$ & $3,002 \%$ & $3,002 \%$ & $76,360 \%$ & $88,336 \%$ \\
\hline
\end{tabular}

Sumber : data olahan hasil penelitian 2015

Kinerja bank danamon tahun 2013 menurun dibandingkan kinerja bank Danamon 2012. Walaupun demikian tapi kalau dilihat dari standar kesehatan bank yang ditetapkan oleh bank Indonesia seperti yang termuat di tabel 4.6 diatas maka bank Danamon masih dikategorikan bank yang sehat.

Kalau kita lihat dari tabel kinerja bank Danamon (tabel 4.8 ) diatas maka terlihat bahwa kinerja bank Danamon 2013 menurun.Penurunan kinerja ini bisa saja disebabkan karena terjadinya penurunan prestasi manajemen dalam menghasilkan pendapatan yang bisa kita lihat dari penurunan rasio NIM. Rasio NIM menurun salah satu sebabnya karena penurunan LDR yang berarti jumlah dana yang tersedia utk dipinjamkan menurun,disamping itu NIM turun juga bisa disebabkan karena kualitas aktiva yang menurun yang bisa dilihat dari penurunan ROA.

\section{City bank}

Tabel 5.9

Kinerja city bank

\begin{tabular}{|c|c|c|c|c|c|}
\hline Tahun & CAR & ROA & NIM & BOPO & LDR \\
\hline 2012 & $19,496 \%$ & $4,055 \%$ & $9,767 \%$ & $73,812 \%$ & $73,850 \%$ \\
\hline 2013 & $15,801 \%$ & $4,181 \%$ & $7,494 \%$ & $85,832 \%$ & $88,336 \%$ \\
\hline
\end{tabular}

Sumber : Data olahan hasil penelitian 2015

Dilihat dari tabel kinerja city bank diatas terlihat bahwa kinerja city bank tahun 2013 turun jika dibandingkan kinerja tahun 2012.Penurunan kinerja ini bukan berarti banknya tidak sehat. Kalau dibandingkan dengan standar kesehatan bank yang tertera pada tabel 4.6 diatas maka city bank ini masih dikategorikan sehat.

Penurunan kinerja city bank diatas salah satu faktornya adalah city bank beroperasi tidak efisien dimana hal ini bisa kita lihat dari peningkatan BOPO nya sehingga terjadi penurunan pada NIM. Berarti disini kinerja manajemen city bank pada tahun 2013 menurun dibandingkan tahun 2012.

\section{KESIMPULAN DAN SARAN}

\section{Kesimpulan}

Berdasarkan hasil penelitian pada bab 5 diatas maka peneliti menarik kesimpulan sebagai berikut :

1. Kinerja bank Permata,bank Danamon dan city bank tahun 2013 menurun jika dibandingkan 2012. 
2.Penurunan kinerja bank Permata,Danamon dan City bank ini tidak sampai mengganggu kesehatannya. Walaupun terjadi penurunan kinerja pada 2013 tetapi ketiga bank diatas masih dikategorikan bank yang sehat

3.Penurunan kinerja ketiga bank yaitu bank Permata,Danamon dan city bank itu sebagian besar disebabkan karena operasi bank yang tidak efisien dimana hal ini bisa kita lihat dari peningkatan BOPO untuk masing-masing bank. Ketiga Bank tersebut mempunyai nilai BOPO yang naik pada tahun 2013 dibandingkan tahun 2012.

\section{Saran}

Berdasarkan hasil penelitian dan pembahasan diatas maka peneliti memberikan sebagai berikut :

1. Bagi bank permata,danamon,dan city bank, peneliti berharap ketiga bank tersebut selalu menganalisa kinerjanya sehingga tahu apa penyebab penurunan dari kinerjanya dan berusaha mengelola kinerjanya sebaik mungkin.

2. Seperti yang sudah disimpulkan diatas bahwa penurunan kinerja tahun 2013 disebabkan karena operasional yang tidak efisien. Cara penanggulangan terhadap ketidak efisienan beban operasional adalah dengan cara menekan biaya. Contohnya diusahakan beban bunga yang dibayarkan bank untuk deposito, tabungan diminimumkan. Meminimumkan beban operasional yang lain selain bunga. Untuk meminimumkan biaya ini, pihak bank perlu melakukan analisa terhadap beban operasional itu sendiri, karena beban operasional tersebut banyak jenisnya bukan hanya beban bunga semata.

3. Bagi peneliti berikutnya yang mau melakukan penelitian yang sama diharapkan waktu pengamatannya agak panjang supaya bisa terlihat dengan jelas penyebab penurunan kinerja.Bisa saja penurunan kinerja ini disebabkan oleh faktor ekstern bank seperti faktor ekonomi.

\section{DAFTAR PUSTAKA}

Citibank.co.id https://www.citibank.co.id

Darmawai, Herman, 2012, Manajemen Perbankan, Jakarta, PT. Bumi Aksara

Dendawijaya, Lukman, 2005, Manajemen Perbankan, Bogor, Ghalia Indonesia

Harmono, 2011, Manajemen Keuangan Berbasis Balanced Scorecard, Jakarta, Bumi Aksara

Hasibuan, Melayu S.P. 2011, Dasar - dasar Perbankan, Jakarta, PT Bumi Aksara

Ismail, 2010, Akuntansi Bank: Teori dan Aplikasi Dalam Rupiah, Jakarta, Kencana

Imam Subaweh, Jurnal Ekonomi Bisnis, No.2, Vol 13, Agustus , 2008

Kartika Wahyu Sukarno, Muhammad Syaichu, Jurnal Studi Manajemen dan

Organisasi, Volume 3, Nomor 2, Juli 2006

Kasmir, 2008, Pemasaran Bank, Jakarta , Kencana

Pandia, Farianto, 2012, Manajemen Dana dan Kesehatan Bank, Jakarta, PT. Rineka Cipta

Permata Bank, https://www.Permata Bank.com

WWW.Danamon.co.id Laporan Tahunan 2014 